\title{
How are MCPIP1 and cytokines mutually regulated in cancer-related immunity?
}

\author{
Ruyi Xu ${ }^{1,2}$, Yi Li ${ }^{1,2}$, Yang Liu ${ }^{1,2}$, Jianwei $\mathrm{Qu}^{1,2}$, Wen Cao ${ }^{1,2}$, Enfan Zhang ${ }^{1,2}$, Jingsong He ${ }^{1,2 \bowtie}$, Zhen Cai ${ }^{1,2 \bowtie}$ \\ ${ }^{1}$ Bone Marrow Transplantation Center, The First Affiliated Hospital, School of Medicine, Zhejiang University, Hangzhou \\ 310006, China \\ 2 Institution of Hematology, Zhejiang University, Hangzhou 310006, China \\ $\triangle$ Correspondence: hejingsong@zju.edu.cn (J. He), caiz@zju.edu.cn (Z. Cai) \\ Received April 9, 2020 Accepted May 11, 2020
}

\begin{abstract}
Cytokines are secreted by various cell types and act as critical mediators in many physiological processes, including immune response and tumor progression. Cytokines production is precisely and timely regulated by multiple mechanisms at different levels, ranging from transcriptional to post-transcriptional and posttranslational processes. Monocyte chemoattractant protein-1 induced protein 1 (MCPIP1), a potent immunosuppressive protein, was first described as a transcription factor in monocytes treated with monocyte chemoattractant protein-1 (MCP-1) and subsequently found to possess intrinsic RNase and deubiquitinase activities. MCPIP1 tightly regulates cytokines expression via various functions. Furthermore, cytokines such as interleukin 1 beta (IL-1B) and MCP-1 and inflammatory cytokines inducer lipopolysaccharide (LPS) strongly induce MCPIP1 expression. Mutually regulated MCPIP1 and cytokines form a complicated network in the tumor environment. In this review, we summarize how MCPIP1 and cytokines reciprocally interact and elucidate the effect of the network formed by these components in cancer-related immunity with aim of exploring potential clinical benefits of their mutual regulation.
\end{abstract}

KEYWORDS MCPIP1, cytokines, cancer-related immunity, RNase, deubiquitinase

\section{INTRODUCTION}

The idea that inflammation contributes to the onset of cancer, which is now well accepted and considered a vital characteristic of cancer, can be traced back to the 19th century (Coussens et al., 2013; Elinav et al., 2013; Coffelt and De Visser, 2014; Maman and Witz, 2018). According to extensive research results over the past decade, approximately $25 \%$ of human cancers are caused by chronic inflammation (Mantovani et al., 2008). In contrast to selflimiting innate inflammation, which acts as a defense for the fight against invading pathogens, persistent and dysregulated chronic inflammation increases the risk of human cancer. As chronic inflammation is related to sustained and continuous tissue damage and repair, it leads to the chaotic proliferation of cells, resulting in accumulation of atypical cell populations and even neoplasia (Prach et al., 1997; Houghton et al., 2004).

The importance of intracellular communication between malignant cells and immune cells within the tumor microenvironment has long been recognized (Stoeltzing et al., 2006). Under stimuli, host immune cells secrete cytokines and other small inflammatory proteins to fight against tumors, but these released cytokines sometimes conversely activate malignant cells, causing specific mutations and epigenetic changes in cancer cells (Galdiero et al., 2018). Correspondingly, highly proliferative cancer cells will produce increased levels of cytokines, attracting immune cells and regulating the gene expression pattern of host cells (Chitu and Stanley, 2006; Colotta et al., 2009).

Cytokines are an indispensable component of the intracellular feedback loop between tumor and host immunity (Diakos et al., 2014). They regulate cancer progression through many mechanisms, including acceleration of the epithelial-to-mesenchymal transition, stimulation of angiogenesis and augmentation of metastasis (Fiori et al., 2019). More specifically, cytokines such as IL-1B, interleukin 6 (IL6), interferon gamma (IFN-y) and interleukin 10 (IL-10) can effectively activate immunosuppressive pathways in myeloid-derived suppressive cells (MDSCs) and induce the differentiation of MDSCs into tumor-protective dendritic and 
macrophage cells (Dysthe and Parihar, 2020). Chemokines, a kind of chemotactic cytokines, also profoundly contribute to promoting tumor progression. Derived from various cell types, chemokines play a key role in the metastatic spread of tumor and are usually overexpressed in highly invasive tumors (Marcuzzi et al., 2019).

In addition to direct regulation by transcription factors, such as NF-KB and STAT3, the regulation of cytokines production by post-transcriptional mechanisms has been well studied (Karin and Greten, 2005; Takeuchi, 2018). Timely and precisely adjusting cytoplasmic concentrations of cytokines mRNA towards different status is important for immunity homeostasis. Although transcription is the first step, many post-transcriptional processes such as mRNA splicing, degradation, polyadenylation and translation are involved in the tight regulation of cytokines (Fu and Blackshear, 2017). For example, restricted TNF production is related to the adenylate-uridylate-rich elements (AREs)mediated and constitutive decay element (CDE)-mediated decay of TNF mRNA (Fu and Blackshear, 2017). Strictly regulation of mRNA turnover kinetics is essential for cells to adjust their translation potential due to diverse stimuli. After cells are activated, the half-lives of the mRNAs of many cytokines are significantly shortened because of mRNA decay (Fu and Blackshear, 2017), in which the newly recognized immunosuppressive protein MCPIP1 plays an important role (Matsushita et al., 2009).

MCPIP1, also known as Regnase-1 and ZC3H12A, a $65.8-\mathrm{kDa}$ member of the $\mathrm{CCCH}$ zinc finger proteins that contains a PilT N-terminus (PIN) domain-like RNase domain and a ubiquitin (Ub)-associated domain at its $\mathrm{N}$-terminus, can act as a regulator of RNA metabolic processes (Xu et al., 2012) (Fig. 1). It recognizes stem-loop structures with specific pyrimidine-purine-pyrimidine loop sequences in the $3^{\prime}$ untranslated regions (3'UTRs) of mRNA and then degrades those transcripts. In addition to directly destabilizing mRNAs by its intrinsic RNase activity, MCPIP1 can act as a deubiquitinating enzyme to regulate protein expression
(Liang et al., 2010). Research results showed that MCPIP1 deubiquitinates TRAF6 by forming a complex with USP10 and TANK. As $\mathrm{CCCH}$ zinc finger proteins usually shuttle between cellular compartments, MCPIP1 was first found in the nucleus when MCPIP1-GFP was expressed in HEK293 cells (Mino et al., 2015), but some studies then identified MCPIP1 on ribosomes on the endoplasmic reticulum, and some studies indicated that MCPIP1 could form granule-like structures in the cytoplasm that interact with the miRISC to regulate miRNA effector pathways (Huang et al., 2015).

In this review, we focus on how MCPIP1 regulates inflammatory cytokines expression in the cancer microenvironment though its various functional domains and identify a feedback loop between MCPIP1 and cytokines, exploring feasible strategies to disturb or reinforce their mutual effects to benefit clinical practice.

\section{HOW DOES MCPIP1 REGULATE CYTOKINES PRODUCTION?}

Great effort has been made to elucidate the mutual regulation between MCPIP1 and cytokines (Xu et al., 2012). In the following section, we discuss four common mechanisms by which MCPIP1 tightly regulates cytokines production and maintains immune homeostasis. We have summarized this mutual regulatory network in Fig. 2. Considering cytokines and MCPIP1 may act differently in human and murine system, we also summarized experimental models used in studies in Table 1, which suggests the interplay between cytokines and MCPIP1 is similar in both species.

\section{At the transcriptional level}

MCPIP1 was first described as a transcription factor in human monocytes after treatment with MCP-1(Zhou et al., 2006). The transcription factor-like activity of MCPIP1 was confirmed by luciferase reporter system. HEK293 cells cotransfected with GAL4-MCPIP1 and pGal4-Luc reporter
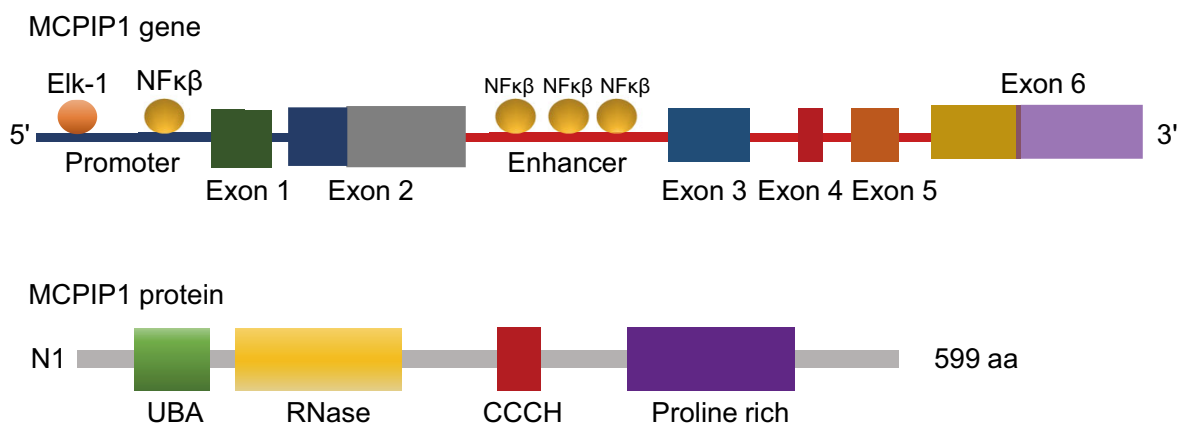

Figure 1. Schematic structures of human MCPIP1 gene and protein. The binding sites of transcription factors Elk-1 and NF-K $\beta$ are showed in MCPIP1 gene. The location of promoter, Enhancer and Exons are also indicated in MCPIP1 gene. The protein domains are presented. UBA: ubiquitin-associated domain; RNase: ribonuclease domain. 
showed MCPIP1 activated luciferase reporter gene transcription to $865-$ fold $/ \mathrm{mg}$ protein and mutation of the $\mathrm{CCCH}$ zinc finger domain or proline-rich domain was found to drastically affect its transcriptional activity. It is determined that the transcription factor-like activity of MCPIP1 contributes to apoptotic genes transcription and leads to cell death. Another study showed that MCPIP1 can act as a transcription factor by CHIP analysis, with the results indicating that Cadherin $12(\mathrm{CDH12})$ and $\mathrm{CDH} 19$ are targets of MCPIP1 (Niu et al., 2008). MCPIP1 transcriptionally activates the expression of these angiogenesis-related genes, thus promoting capillary-like tube formation.

In addition, MCPIP1 regulates genes transcription by interacting with other potent transcription factors. LPS-induced TLR signaling activation is critical for immune defense to infection. Stimulation of macrophages by LPS strongly activates multiple signaling pathways to rapidly release proinflammatory cytokines, such as TNFa, IL-1B, IL-6, IL-12, and IL-18 (Wynn et al., 2013). The NF-KB pathway plays an important role in regulating proinflammatory cytokines expression. The results from Liang et al. showed that MCPIP1, unlike other $\mathrm{CCCH}$ zinc finger proteins, does not regulate TNF or MCP-1 mRNA stability and does not work with other proteins to affect AREs-mediated TNF mRNA decay. Interestingly, Overexpressed MCPIP1 directly inhibited p65-induced promoter activation of TNF and iNOS in LPS treated cells (Liang et al., 2008). The block effect is specific as MCPIP1 can't inhibit PPAR y-induced PPREs promoter activation. Moreover, Huang et al. showed that MCPIP1 inhibited proinflammatory cytokines production by negatively regulated LPS-induced JNK signaling. Increased LPS-induced phosphorylated JNK was found in the lung of MCPIP1-deficient mice (Huang et al., 2013).

\section{At the post-transcriptional level}

Cytokines production in an organism is strictly regulated starting from transcriptional initiation and ending with mature mRNA translation to a protein. The effect of post-transcriptional regulation is critical during this process.

$\mathrm{CCCH}$ zinc finger proteins can act as RNA-binding proteins to regulate cytokines transcripts metabolism ( $\mathrm{Fu}$ and Blackshear, 2017). A massive number of studies have shown that MCPIP1 can directly target and degrade proinflammatory cytokines transcripts, acting as a negative regulator of inflammation. In contrast to tristetraprolin (TTP), a well-known member of $\mathrm{CCCH}$ zinc finger proteins that mediates mRNA decay by binding to AREs in the $3^{\prime} U T R$ s of mRNAs, MCPIP1 binds and cleaves a specific stem-loop sequence in the $3^{\prime} U T R$ s through its intrinsic endonuclease activity.

Let us take IL-6 as an example. IL- 6 is a multifunctional proinflammatory cytokine, that plays an important role in various diseases. Many studies have shown that MCPIP1 can tightly regulate IL-6 production through its RNase activity (Matsushita et al., 2009). MCPIP1 ${ }^{-/-}$mice exhibited severe autoimmune disease, with significant splenomegaly and lymphadenopathy, and usually died within 12 weeks of birth. $\mathrm{MCPIP}^{-/-}$macrophages exhibited highly increased production of IL-6 and IL-12B under TLR ligand stimulation. PIN domain mutation abolished MCPIP1 RNase activity and prevented shortening of the IL6 mRNA half-life. In adaptive immunity, MCPIP1 was shown to negatively regulated IL-17mediated signaling by destabilizing IL6 mRNA. Garg et al. found that the RNase activity of MCPIP1, but not its DUB function, is crucial in controlling the expression of various IL17 induced genes (Garg et al., 2015). In addition to IL6, MCPIP1 degrades IL17RA and IL17RC mRNA and strongly inhibits the LCN2 promoter activity by accelerating NFKBIZ mRNA decay (Monin et al., 2017). Interestingly, Mino et al. showed that MCPIP1 can collaborate with Roquin1, another $\mathrm{CCCH}$ zinc finger protein, to control IL-6 production (Mino et al., 2015). Both proteins recognize a common stem-loop structure but promote the IL6 mRNA decay at different inflammatory response phases: MCPIP1 regulates the IL6 mRNA decay at the early inflammatory phase by relying on the helicase activity of UPF1, mainly decreasing actively translated mRNAs, while Roquin 1 controls IL6 mRNA decay at the later inflammatory phase by removing inactively translated mRNA.

Miao et al. compared inflammatory cytokines levels in the serum of MCPIP1 $1^{-/-}$and MCPIP1 ${ }^{+/+}$mice (Miao et al., 2013). Their results showed that the mRNAs of the $T$ cell cytokines IL-17, IL-12, IL-4, IL-5 and TNFa were elevated in MCPIP1 ${ }^{-1-}$ mice, but their upstream transcription factors, including T-bet, GATA3 and RORy, were not changed. This result suggested that MCPIP1 directly regulates the metabolism of cytokines transcripts via a post-transcriptional process.

In addition to the $3^{\prime} \mathrm{UTR}$ of transcripts, MCPIP1 was reported to bind other $m R N A$ regions. In work from Jiang et al., MCPIP1 was found to regulate TET mRNA by targeting its coding sequence (Jiang et al., 2016). MCPIP1 knockdown increased TET mRNA levels and then promoted the conversion of $5 \mathrm{mC}$ to $5 \mathrm{hmC}$. Garg et al. also found that MCPIP1 targets the $5^{\prime}$ region of IL17RA mRNA (Garg et al., 2015). Although MCPIP1 possesses intrinsic RNase activity and can cleave diverse mRNAs without sequence preference, the mechanism by which it recognizes its substrates remains unknown.

\section{At the posttranslational level}

MCPIP1 can act as a deubiquitinating enzyme to regulate TRAFs at the protein level. TRAFs are critical in the LPS-, IL1B- and TNF- induced signaling pathway, including JNK and NF-KB activation (Muzio et al., 1998). As inappropriate regulation of the JNK and NF-KB pathways causes inflammation-induced tissue damage or malignancy, both signaling pathways should be tightly controlled to maintain transient activation, in which ubiquitination plays a key regulatory role. TRAFs are linked to K63 polyubiquitin chains early in the 


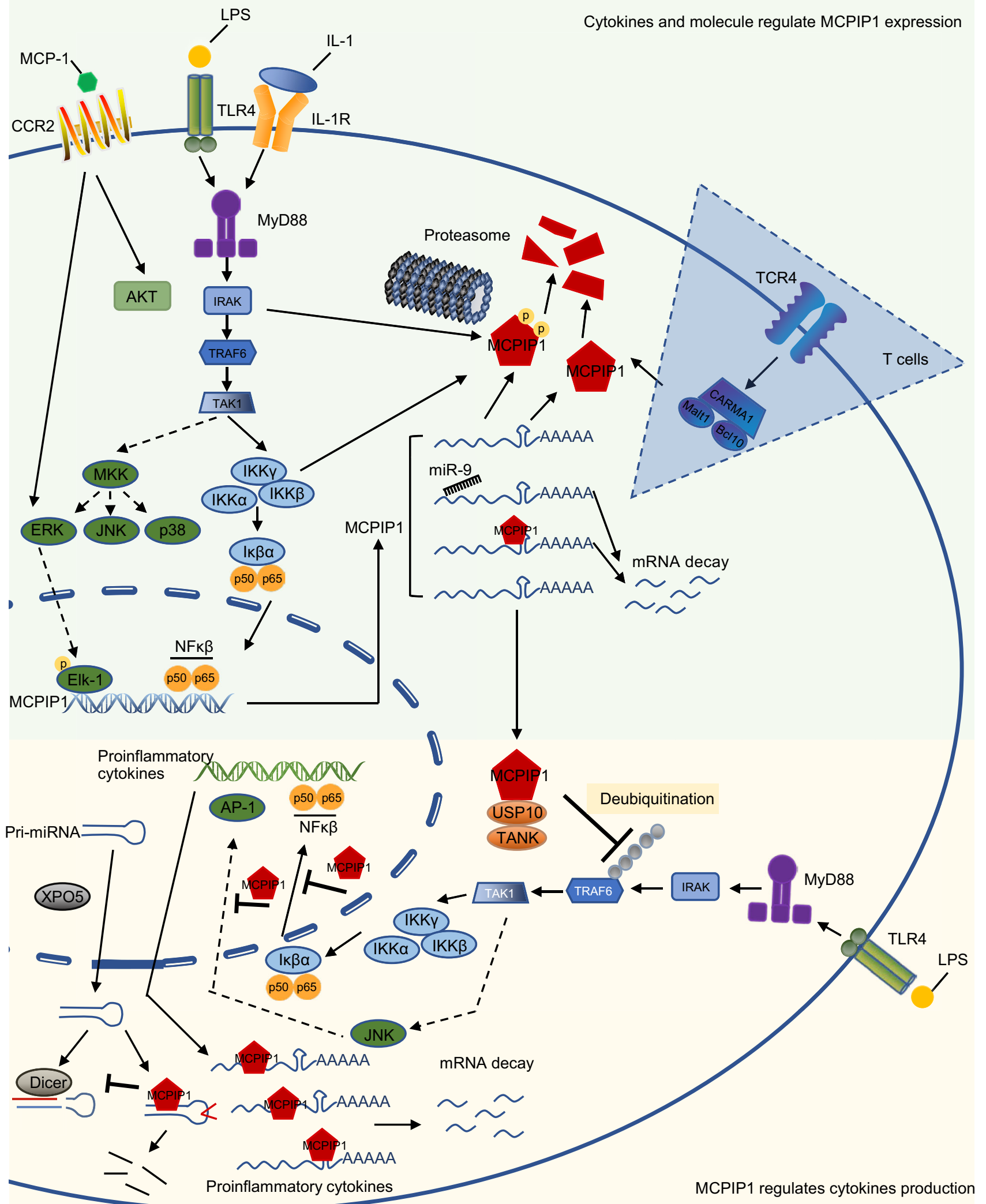


Figure 2. The mechanism how MCPIP1 and cytokines mutually regulated in macrophages. The upper green part indicates the mechanism how cytokines and LPS regulate MCPIP1 expression. Activation of TLR4 by LPS, or IL-1R by IL1 , subsequently activates the inhibitor of NF-K $\beta$ kinase (IKK) complex, leading to the phosphorylation and degradation of IKB $\alpha$. Then NF-K $\beta$ is released and translocate to the nucleus to induce the transcription of MCPIP1 gene. MAPkinase pathway is also activated and phosphorylated Elk-1 promotes MCPIP1 transcription. Post-transcriptional regulation happened in cytoplasm, MCPIP1 mRNAs interact with miR-9 or MCPIP1 protein and undergo degradation. Those translated MCPIP1 protein can be phosphorylated by NF-K $\beta$ signaling and then degraded by proteasome machinery. The blue triangle indicates a different mechanism of MCPIP1 protein degradation in T cells. It's mediated by protease Malt1. The Lower yellow part indicates the mechanism how MCPIP1 protein regulates cytokines production. MCPIP1 interacts with USP10 and TANK to inhibit NF-K $\beta$ signaling by deubiquitinating the activated TRAF6. In cytoplasm, MCPIP1 interacts with cytokines transcripts to induce mRNA decay. In addition, its anti-Dicer RNase activity inhibits miRNAs maturation. In nucleus, MCPIP1 directly inhibits translocated $\mathrm{NF}-\mathrm{K} \beta$ and $\mathrm{AP}-1$ bind to the target proinflammatory cytokines genes, then suppresses proinflammatory cytokines transcription.

cellular response, which does not lead to protein degradation but is important for signal transduction (Deng et al., 2000).

MCPIP1 contains a unique DUB domain with no essential sequence similar to those in the five known DUB domains and possesses intrinsic deubiquitinase activity (Liang et al., 2010). Results have suggested that both PIN domain at the $\mathrm{N}$-terminal region and the $\mathrm{CCCH}$ zinc finger domain are important for the deubiquitinatase activity of MCPIP1. The D141N, C157A, and C306R point mutations of MCPIP1 abolished its deubiquitinatase function, and the $\mathrm{D} 141 \mathrm{~N}$ mutation was also associated with its RNase activity. MCPIP1 could cleave both K48- and K63- linked polyubiquitin. Furthermore, MCPIP1 expression significantly decreased TRAF2 and TRAF6 ubiquitination and affects the K48-linked ubiquitination of IKBa.

In addition to its intrinsic deubiquitinatase activity, MCPIP1 was found to inhibit genotoxic NF-KB activation in a manner dependent on USP10, a member of the ubiquitin specific protease (USP) family (Niu et al., 2013). USP10 is recruited by MCPIP1 to cleave linear polyubiquitin chains from NF-KB essential modulator (NEMO), resulting in IKK activation and subsequent inhibition of NF-KB activation induced by DNA damage. Genotoxic treatment also induced the production of inflammatory cytokines through NF-kB signaling. Results showed that the mRNA levels of IL-6, TNFa and Cox-2 were substantially increased in MCPIP1 ${ }^{-/-}$ cells. Consistently, USP10 knockdown rescued MCPIP1mediated repression of DNA damage-induced inflammatory cytokine production. Their results showed that MCPIP1 can affect DNA damage signaling in cells after genotoxic treatment.

The deubiquitinatase activity of MCPIP1 contributes to macrophages polarization as well. Macrophages can be simply classified into 2 extreme types, M1 macrophages and M2 macrophages (Murray et al., 2014). When macrophages are stimulated by a variety of signals, such LPS or IL-1B, they are polarized to the $M 1$ type and release proinflammatory cytokines, thus playing a protective role in the organism. In contrast, M2 macrophages are usually found in the tumor microenvironment, where they protect malignant cells through their immunosuppressive function (Gordon and Martinez, 2010). Kapoor et al. reported that the polarization of macrophages with DUB mutant and/or RNase mutant MCPIP1 to M2 type was much less effectively than the polarization of control macrophages. Loss of the deubiquitinatase activity of MCPIP1 inhibited IL-4 induced STAT6 and KLF4 activity and subsequently inhibit macrophages M2 polarization (Kapoor et al., 2015).

Importantly, MCPIP1 participates in the process of immune elimination of cancer cells. Death receptor 5 (DR5) is a cell surface marker that binds TNF-related apoptosisinducing ligand (TRAIL). TRAIL is expressed by different immune cells, especially cytotoxic $T$ cells. The binding of DR5 to TRAIL recruits Fas-associated death domain (FADD) to the cytoplasmic part of DR5 in cancer cells, after which FADD interacts with procaspase-8, forming the death-inducing signaling complex (DISC), which activates the caspase pathway to induce cell apoptosis. MCPIP1 inhibits the polyubiquitination of DR5 via its DUB activity and then enhance DR5 lysosomal degradation, resulting in resistance to DR5 activation or TRAIL-induced cancer cell apoptosis (Oh et al., 2018). MCPIP1 does not alter DR5 mRNA levels but destabilizes DR5 protein through a posttranslational mechanism. The C157A mutation of MCPIP1 confirmed that DUB activity promotes autophagic/lysosomal degradation of DR5 and subsequently inhibits DISC formation.

\section{By inhibiting miRNA synthesis}

Emerging studies have shown that miRNA expression is critical during the immune responses. Mice overexpressing miR-17-92 and miR-155 exhibited severe autoimmune and lymphoproliferative disease (Xiao et al., 2008; Costinean

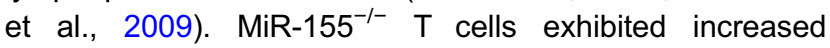
expression of IL-4 (Rodriguez et al., 2007). MiRNA biogenesis was shown to be dynamically regulated by productive and abortive ribonucleases. MCPIP1 was reported to target the terminal loops of pre-miRNAs through its NYN nuclease domain, inhibiting miRNA synthesis (Suzuki et al., 2011). The ribonuclease function of MCPIP1 was found to compete with Dicer, a central ribonuclease in miRNA processing. MCPIP1 recognizes pre-miRNA through a vertebrate-specific oligomerization and preferentially cleaves the unpaired region of pre-miRNA near the terminal loop. Taking 
Table 1. The interplay between cytokines and MCPIP1

\begin{tabular}{|c|c|c|c|}
\hline & $\begin{array}{l}\text { Substrates/ } \\
\text { Regulators }\end{array}$ & Models & Effect \\
\hline \multirow[t]{8}{*}{$\begin{array}{l}\text { MCPIP1 regulates } \\
\text { cytokines } \\
\text { production }\end{array}$} & TNFa & $\begin{array}{l}\text { Mouse macrophage cell line } \\
\text { RAW264.7 (Liang J et al., 2008) } \\
\text { MCPIP1 }^{-1-} \text { mice (Huang S et al., } \\
\text { 2013) } \\
\text { Mouse Embryonic Fibroblasts (MEF) } \\
\text { (Niu J et al., 2013) } \\
\text { MCPIP1 myelo-KO mice peritoneal } \\
\text { macrophages (Kapoor N et al. } \\
\text { 2015) } \\
\text { Human HepG2 cell line (Skalniak L } \\
\text { et al., 2009) }\end{array}$ & $\begin{array}{l}\text { Inhibits p65-induced promoter activation of TNF } \\
\text { in LPS treated cells; } \\
\text { Inhibits LPS-activated JNK signaling } \\
\text { Prevents NF-kB activation by removing the } \\
\text { ubiquitins from TRAF6; } \\
\text { Suppresses the synthesis of miR155 and miR125 }\end{array}$ \\
\hline & IL-6 & $\begin{array}{l}\text { MCPIP } 1^{-/-} \text {mice macrophage } \\
\text { (Matsushita K et al., 2009) } \\
\text { Mouse stromal cell line ST-2 (Garg A } \\
\text { et al., 2015) } \\
\text { Mouse macrophage cell line } \\
\text { RAW264.7 (Mino T et al., 2015) } \\
\text { Mouse Embryonic Fibroblasts (MEF) } \\
\text { (Niu J et al., 2013) (Mino T et al., } \\
\text { 2015) } \\
\text { Human HeLa cell line (Mino T et al., } \\
\text { 2015) } \\
\text { Human HEK293 cell line (Mino T } \\
\text { et al., 2015) }\end{array}$ & $\begin{array}{l}\text { Destabilizes IL6 mRNA; } \\
\text { Inhibits NF-KB activation }\end{array}$ \\
\hline & $\mathrm{IL}-12$ & $\begin{array}{l}\text { MCPIP1 }^{-1-} \text { mice macrophage } \\
\text { (Matsushita K et al., 2009) }\end{array}$ & Destabilizes IL12p40 mRNA \\
\hline & MCP-1 & $\begin{array}{l}\text { MCPIP1 myelo -KO mice peritoneal } \\
\text { macrophages (Kapoor N et al., } \\
\text { 2015) } \\
\text { Mouse macrophage cell line } \\
\text { RAW264.7 (Liang J et al., 2008) }\end{array}$ & $\begin{array}{l}\text { Suppresses the synthesis of miR155 and } \\
\text { miR125; } \\
\text { Inhibits NF-KB activation }\end{array}$ \\
\hline & IL-2 & $\begin{array}{l}\text { Mouse CD4 } 4^{+} \text {T lymphocytes (Li M } \\
\text { et al., 2012) } \\
\text { Human blood CD4 } 4^{+} \text {T lymphocytes } \\
\text { (Li M et al., 2012) }\end{array}$ & Destabilizes IL2 mRNA \\
\hline & IL-1B & $\begin{array}{l}\text { Human skin fibroblasts (Mizgalska D } \\
\text { et al., 2009) }\end{array}$ & Destabilizes mRNA \\
\hline & IL-8 & $\begin{array}{l}\text { Human HeLa cells (Dobosz E et al., } \\
2016 \text { ) } \\
\text { Human Caco-2 cell line (Dobosz E } \\
\text { et al., 2016) }\end{array}$ & Destabilizes IL8 mRNA \\
\hline & $\mathrm{IL}-4$ & $\begin{array}{l}\text { MCPIP } 1^{-/-} \text {mice spleen cells (Miao R } \\
\text { et al., 2013) } \\
\text { Human Jurkat T cells (Suzuki H } \\
\text { et al., 2011) }\end{array}$ & $\begin{array}{l}\text { Destabilizes IL4 mRNA } \\
\text { Suppresses the synthesis of miR155; }\end{array}$ \\
\hline
\end{tabular}


Table 1 continued

\begin{tabular}{|c|c|c|c|}
\hline & $\begin{array}{l}\text { Substrates/ } \\
\text { Regulators }\end{array}$ & Models & Effect \\
\hline \multirow[t]{7}{*}{$\begin{array}{l}\text { Cytokines and } \\
\text { molecules regulate } \\
\text { MCPIP1 expression }\end{array}$} & TNFa & $\begin{array}{l}\text { Human THP-1 cells (Liang J et al., } \\
\text { 2008) } \\
\text { Human umbilical vein endothelial } \\
\text { cells (HUVECs) (Qi Y et al., 2010) } \\
\text { Human U937 cell line (Mizgalska D } \\
\text { et al., 2009) }\end{array}$ & Induces MCPIP1 expression \\
\hline & MCP-1 & $\begin{array}{l}\text { Mouse macrophage cell line } \\
\text { RAW264.7 (Zhou L et al., 2006) } \\
\text { Human peripheral blood monocytes } \\
\text { (Zhou L et al., 2006) } \\
\text { Human HUVECs (Niu J et al., 2008) }\end{array}$ & $\begin{array}{l}\text { Induces Elk-1 phosphorylation } \\
\text { Activates Akt signaling }\end{array}$ \\
\hline & IL-4 & $\begin{array}{l}\text { Mouse peritoneal macrophages } \\
\text { (Kapoor } \mathrm{N} \text { et al., 2015) }\end{array}$ & Induces KLF4 to activate MCPIP1 transcription \\
\hline & IL-1B & $\begin{array}{l}\text { MCPIP }^{-/-} \text {mice peritoneal } \\
\text { macrophages and MEFs (Iwasaki } \\
\text { H et al., 2011) } \\
\text { Human THP-1 cells (Liang J et al., } \\
\text { 2008) } \\
\text { Human HepG2 cell line (Skalniak L } \\
\text { et al., 2009) (Mizgalska D et al., } \\
\text { 2009) }\end{array}$ & $\begin{array}{l}\text { Activates NF-KB signaling and ERK MAPkinase } \\
\text { pathway to induce MCPIP1 expression; } \\
\text { Activates IRAK1 and IKK } \beta \text { to phosphorylate } \\
\text { MCPIP1 protein which undergoes degradation } \\
\text { by ubiquitin proteasome; } \\
\text { Upregulates MCPIP1 protein to destabilize } \\
\text { MCPIP1 mRNA itself }\end{array}$ \\
\hline & $\mathrm{IL}-1 \alpha$ & $\begin{array}{l}\text { Human synovial fibroblasts from a } \\
\text { patient with osteoarthritis (Dhamija } \\
\text { S et al., 2013) }\end{array}$ & $\begin{array}{l}\text { Increases ribosome occupancy of MCPIP1 } \\
\text { mRNA }\end{array}$ \\
\hline & IL-17 & $\begin{array}{l}\text { Mouse stromal cell line ST-2 (Garg A } \\
\text { et al., 2015) } \\
\text { Primary mouse embryo fibroblasts } \\
\text { (Sønder S et al., 2011) } \\
\text { Human HeLa cells (Dhamija S et al., } \\
\text { 2013) } \\
\text { Human oral keratinocytes (Garg A } \\
\text { et al., 2015) }\end{array}$ & $\begin{array}{l}\text { Stabilizes MCPIP1 mRNA; } \\
\text { Recruits CIKS/Act1 to activate NK-KB and then } \\
\text { induce MCPIP1 expression }\end{array}$ \\
\hline & LPS & $\begin{array}{l}\text { Mouse RAW264.7 (Liang J et al., } \\
\text { 2008); (Huang S et al., 2013) } \\
\text { (Dhamija S et al., 2013) } \\
\text { Mouse bone marrow-derived } \\
\text { macrophages (Liang J et al., 2008) } \\
\text { Rat microglial cells (Yao H et al., } \\
\text { 2014) } \\
\text { MCPIP1 }^{-/-} \text {mice peritoneal } \\
\text { macrophages and MEFs (Iwasaki } \\
\text { H et al., 2011) } \\
\text { Human THP-1 derived macrophages } \\
\text { (Liang J et al., 2008) } \\
\text { Human peripheral blood } \\
\text { mononuclear cells (Dhamija S } \\
\text { et al., 2013) }\end{array}$ & $\begin{array}{l}\text { Activates NF-KB signaling and ERK MAPkinase } \\
\text { pathway } \\
\text { Inhibits miR-9 to stabilize MCPIP1 mRNA } \\
\text { Activates IRAK1 and IKK } \beta \text { to phosphorylate } \\
\text { MCPIP1 protein which undergoes degradation } \\
\text { by ubiquitin proteasome }\end{array}$ \\
\hline
\end{tabular}

macrophages polarization as an example, TNFa upregulated miR155 expression and subsequently polarized macrophages to the M1 type. MCPIP1 suppressed the synthesis of miR155 and upregulated M2 polarization-associated miR223 and miR146 expression (Miao et al., 2013).
Nevertheless, whether MCPIP1 can regulate inflammatory cytokines mRNA by controlling miRNAs is controversial. Mino et al. reported that expression of the LPS-induced miRNAs such as miR155 and miR146 was not altered in mouse embryonic fibroblasts from $\mathrm{MCPIP}^{-/-}$mice and that 
miRNAs were not enriched by MCPIP1 CLIP-seq (Mino et al., 2015). In summary, further studies are needed to uncover whether miRNAs synthesis patriciates in MCPIP1regulated cytokine production.

\section{HOW DO CYTOKINES REGULATE MCPIP1 EXPRESSION?}

Various cells can express MCPIP1 and regulate their expression at different mechanistic levels, including the transcriptional, post-transcriptional and posttranslational levels. In the following section, we focus on how cytokines precisely inversely regulate MCPIP1 expression due to immune stimuli at different levels.

\section{At the transcriptional level}

IL-1B interacts with IL-1R, initiating the adaptor protein myeloid differentiation primary response gene 88 (MyD88), which activates NF-KB signaling and subsequently upregulates the expression of MCPIP1 (Skalniak et al., 2009). MCPIP1 possesses four functional NF-kB binding sites within its second intron region and two NF-KB binding sites within its promoter sequence. NF-kB inhibitor $\mathrm{kB}(\mathrm{I} \mathrm{KB})$ has been confirmed to inhibit IL-1B induced MCPIP1 expression. In addition to NF-KB, Myd88 activates mitogen-activated protein kinase (MAPkinase) signaling. ERK MAPkinase pathway activation phosphorylates the transcription factor Elk-1, which binds to the promoter region of MCPIP1, initiating its transcription (Kasza et al., 2010). LPS, a potent inflammatory cytokines inducer, binds TLR4 and then induces the expression of MCPIP1 through the same signaling pathway as IL-1B/IL1R (Huang et al., 2013). LPS/TLR4 recruits Myd88 and then activated NF-KB and ERK MAPkinase signaling as well. In addition to IL-1B and LPS binding, the binding of MCP-1 to its receptor, CCR2, induces Elk-1 phosphorylation and promotes MCPIP1 transcription (O'Boyle et al., 2007). Serine/threonine-specific protein kinase (Akt) activation is also involved in MCP-1 induced MCPIP1 transcription.

At the post-transcriptional level and posttranslational level

At the post-transcriptional level, MCPIP1 mRNA was found to be regulated by miR-9 in LPS-activated microglial cells (Yao et al., 2014). MiR-9 targets the MCPIP1 3'UTR and subsequently downregulates the expression of MCPIP1. Additionally, MCPIP1 mRNA can be self-regulated by the MCPIP1 protein via its RNase activity (Yao et al., 2014). MCPIP1 targets the conserved stem-loop structure in the MCPIP1 3'UTR, similar to the IL6 mRNA degradation process, inhibiting MCPIP1 expression, and forming a negative feedback loop.

The mechanisms of MCPIP1 protein degradation in macrophages and $\mathrm{T}$ cells differ. Proteasomal degradation plays a key role in MCPIP1 degradation in macrophages (Iwasaki et al., 2011). Upon stimulation with TLR ligands, MCPIP1 is rapidly phosphorylated by IRAK1 and IKB kinase (IKK) $\beta$ and then undergoes degradation via the UB-proteasome machinery. Both IRAK1 and IKK $\beta$ are the downstream of MyD88, which suggests that when TLRs and IL-1R are stimulated by LPS or IL-1B, the activation of NF-kB signaling not only promotes MCPIP1 transcription but also ready to degrade expressed MCPIP1 protein to maintain homeostasis. The mechanism of MCPIP1 protein degradation goes different in T cells. The protease Malt1 mediates MCPIP1 degradation via its linker region between PIN domain and $\mathrm{N}$-terminal domain. Inactive C472A mutant MALT1 failed to cleave MCPIP1 under TCR stimulation (Jeltsch et al., 2014).

\section{WHAT ROLE DOES THE MCPIP1/CYTOKINES NETWORK PLAY IN CANCER?}

\author{
Sustained angiogenesis, tissue invasion \\ and metastasis
}

Limitless replication of cancer cells demands massive amounts of nutrition and oxygen. Angiogenesis, the formation of new blood vessels in the tumor microenvironment, guarantees a sufficient supply for growing malignant cells (Folkman, 2002). New vessels can be formed from circulating bone marrow-derived endothelial progenitor cells (BMEPCs) or form directly from pre-existing vessels. Inflammatory is the main inducer of angiogenesis in cancer. Many studies have showed that proinflammatory cytokines, such as MCP-1, IL-1B, and IL-6, induce angiogenesis and promote tumor growth, invasion and metastasis (Voronov et al., 2003; Ono, 2008).

The effect of MCPIP1 in angiogenesis is controversial. Marona et al. reported that MCPIP1 expression is negatively correlated with clear cell renal cell carcinoma (ccRCC) progression and tumor vascularity (Marona et al., 2017). They found that MCPIP1 cleaves IL8, VEGF and CXCL12 mRNA via its RNase activity, leading to the impaired chemotaxis of BM-EPCs, phosphorylation of VE-cadherin and vascular permeability. Mechanistic studies showed that decreased MCPIP1 in ccRCC is associated with increased SDF-1 and CXCR4 expression, which work together to promote tumor invasion and metastasis. However, Roy et al. showed MCPIP1 promotes angiogenesis in human umbilical vein endothelial cells (HUVECs) by inhibiting the production of antiangiogenetic miR-20b and miR-34a, which repress the translation of HIF-1 $\alpha$ and SIRT-1 respectively (Roy et al., 2013). Niu et al. showed MCPIP1 activated the expression of angiogenesis-related gene $\mathrm{CDH} 12$ and $\mathrm{CDH} 19$ via its transcription factor activity in HUVECs, and then promoted vascularization (Niu et al., 2008). MCPIP1 may exhibit diverse actions according to normal or pathological conditions, but as limited amount of studies has been conducted, 
more evidences are needed to elucidate the behavior of MCPIP1 in cancer angiogenesis.

\section{Cancer cells apoptosis and replicative potential}

Accumulating evidence has demonstrated that MCPIP1 acts as a potent tumor suppressor and induces cancer cells apoptosis. Studies in breast cancer showed that MCPIP1 directly binds and cleaves the mRNAs of multiple antiapoptotic genes, such as $B C L 2 A 1, B C L 2 L 1$, and $R E L B$, and subsequently induces tumor cells apoptosis (Lu et al., 2016). In addition, miRNAs contribute to the proapoptotic activity of MCPIP1. Overexpression of MCPIP1 downregulated miR3613-3p expression in neuroblastoma cells, which then upregulates apoptotic protease activating factor 1 (APAF1), causing cells apoptosis by caspase- 9 proteolysis (Boratyn et al., 2016).

Limitless proliferation is another vital hallmark of cancer. In ccRCC cells, MCPIP1 depletion was found to significantly enhanced tumor cell viability and proliferation (Marona et al., 2017). MCPIP1 knockdown cells were observed to develop into larger tumor mass in NOD-SCID mice. Additionally, regulation of the microRNAs, including miR-155 and miR146a, by MCPIP1 was reported not only to be involved in immune responses, but also to participate in tumor proliferation (Suzuki et al., 2011).

\section{Impaired immune cells activation}

Macrophages in the tumor microenvironment are usually polarized to the M2 type. M2 macrophages release anti-inflammatory cytokines, such as IL-10, promoting tumor cells proliferation and protecting malignant cells from chemotherapy induced apoptosis (Zheng et al., 2013; Murray, 2017; Singhal et al., 2019). Our previous work revealed that increased MCP-1 in the bone marrow in multiple myeloma induced MCPIP1 expression in macrophages. Overexpressed MCPIP1 polarized macrophages to the M2 type and promoted their ability to protect tumor cells via dual catalytic activities, resulting in drug resistance in myeloma cells (Xu et al., 2019).

As MCPIP1 is highly expressed in T cells, its function in T cells activation is of interest. A very large number of studies have shown that MCPIP1 negatively regulates $T$ cells activation through various mechanisms, such as degradation of the immunoregulatory mRNAs ICOS and REL (Uehata et al., 2013). Moreover, MCPIP1 regulates DR5 expression through its deubiquitinase activity (Oh et al., 2018). DR5 expressed on the surface of cancer cells, can be recognized by TRAIL from cytotoxic $\mathrm{T}$ cells, inducing cancer cells apoptosis. Thus, downregulation of MCPIP1 in cancer cells decreases the effect of immune surveillance. Furthermore, the effect of MCPIP1 on the activation of other immune cells, such as B cells, natural killer cells and dendritic cells, remains to be determined.

\section{HOW DOES CLINICAL MANAGEMENT BENEFIT FROM THE MCPIP1/CYTOKINES NETWORK?}

Although the interplay between immunity and cancer is complicated, researchers and clinicians are eager to translate novel, inspiring findings into practical, realistic management strategies.

Cytokines are the focus of immunity in cancer. There are simply two strategies of cytokines targeting in cancer management: nonselective inhibition and specific regulation. In nonselective strategies, systemic inflammation is broadly inhibited via unknown targets. Both non-steroidal anti-inflammatory drugs (NSAIDs) and steroid drugs have therapeutic potential in cancer treatment. Evidences has shown that NSAIDs can limit systemic inflammation and improve cachexia. In several clinical studies of colorectal cancer, NSAIDs used as adjuvant therapy and presented promising benefits (Gierach et al., 2008; Algra and Rothwell, 2012; Rothwell et al., 2012). Steroid drugs such as dexamethasone are more practical than NSAIDs in cancer treatment (Leggas et al., 2009). For example, dexamethasone is an indispensable part of almost every chemotherapy regimen in the treatment of multiple myeloma. The use of dexamethasone improves the efficiency of chemotherapy and decreases drugs-associated toxic effects (Garderet et al., 2018).

For the selective targeting of specific cytokines, although multiple early-phase clinical trials are being conducted, there are few ideal drugs have been found to be effective in clinical practice, as observed in research studies. For instance, Carlumab, an MCP-1 specific monoclonal antibody, can directly against the binding of MCP-1 to its receptor, inhibiting downstream signaling activation and overcoming MCP-1 promoted tumor progression (Brana et al., 2015). Carlumab was proven to have promising beneficial antitumor properties in preclinical studies, but a phase $1 \mathrm{~b}$ clinical study showed that it could not sustainably inhibit the serum MCP-1 concentration in patients; thus, further clinical use of Carlumab is not recommended. The complexity of crosstalk and compensation within the tumor microenvironment might explain the failure of specific cytokines-targeted drugs in cancer treatment.

This failure is why we switch our focus to the downstream regulator MCPIP1. Multiple studies have shown that MCPIP1 is important during the tumorigenesis, including that in neuroblastoma, ccRCC and breast cancer cells (Boratyn et al., 2016; Lu et al., 2016; Marona et al., 2017). In ccRCC, the MCPIP1 expression is negatively correlated with tumor grade. The same negative correlation was observed in breast cancer, and decreased MCPIP1 expression is associated with enhanced metastatic characteristics. Considering the expression profile of MCPIP1 in tumor progression, it has the potential to act as a potent prognosis marker in cancers. However, further studies in more cancer types are needed to uncover the predictive value of MCPIP1.

Moreover, a growing number of studies contributed to interfere the effect of MCPIP1 to explore its role in cancer 
treatment. It has been reported that MG-132, a proteasome inhibitor, effectively upregulates MCPIP1 expression, potently activating the apoptosis of cancer cells (Skalniak et al., 2013). However, as MCPIP1 acts as an immumosuppressor in cancer-related immunity, MCPIP1 expression has extremely different effects in immune cells and cancer cells. Cancer cells benefit from downregulated MCPIP1, which is related to increased antiapoptotic gene mRNA expression and decreased expression of DR5 on the cancer cell surface. All these effects protect cancer cells from death. In contrast, downregulated MCPIP1 polarizes macrophages to the M1 type and promotes immune activation of $\mathrm{T}$ cells. Specific downregulation of MCPIP1 expression can enhance the antitumor effect of immune cells. Therefore, determining how to specifically interfere with MCPIP1 expression in cancer cells or immune cells is a major challenge for translating research findings to clinical practice.

\section{CONCLUSION AND PERSPECTIVES}

Cytokines have extremely vital and complicated biological functions, and their abnormal expression is involved in many pathological processes, including autoimmune disease and cancers. Various cell types and multiple mechanisms participate in the tight regulation of cytokines production. MCPIP1, which possesses a unique deubiquitination domain and has intrinsic RNase activity, was reported to effectively inhibit immune activation. However, the role of MCPIP1 in cancer has not drawn sufficient attention to date and only a few studies on this topic have been published.

MCPIP1 is at the center of cytokines regulatory networks. It mutually regulates cytokines at several levels, ranging from transcriptional to post-transcriptional and posttranslational processes. Moreover, specific cytokines can regulate other cytokines and MCPIP1 also has a negative feedback effect on itself. Cytokines and MCPIP1 work together to form a complicated network to precisely and timely regulate intracellular responses in the cancer environment. It is well established that cytokines expression associated with tumor progression and that some specific cytokines can act as prognostic markers. However, very few direct cytokines-targeting drugs have shown promising effects in clinical trials. And there are also no MCPIP1-targeting drugs available yet in pre-clinical or clinical studies. Thus, further studies should be conducted to determine whether interference with the crosstalk between cytokines and MCPIP1 has potential benefits in cancer treatment, and more studies are needed to elucidate the role of MCPIP in cancer.

\section{AUTHORS' CONTRIBUTION}

ZC. and JS.H. initiated the study and supervised the project. RY.X. and Y.L. devised the main conceptual ideas. RY.X. wrote the manuscript in consultation with EF.Z.. Y.L., JW.Q., W.C. participated in investigating related results. All authors contributed to the final manuscript.

\section{ABBREVIATIONS}

APAF1, apoptotic protease activating factor 1; AREs, adenylateuridylate-rich elements; BM-EPCs, bone marrow-derived endothelial progenitor cells; CCR2, C-C motif chemokine receptor 2; ccRCC, clear cell renal cell carcinoma; CDE, constitutive decay element; $\mathrm{CDH}$, cadherin; CHIP, chromatin immunoprecipitation; CLIP-seq, crosslinking immunoprecipitation sequencing; DISC, death-inducing signaling complex;DR5, death Receptor 5; DUB, deubiquitinating; FADD, Fas-associated death domain; GATA3, GATA binding protein 3; HUVECs, human umbilical vein endothelial cells; ICOS, inducible T cell co-stimulator; IFN, interferon; IL, interleukin; LPS, lipopolysaccharide; IL17RA, interleukin 17 receptor A; IL17RC, interleukin 17 receptor C; IL-1R, interleukin-1 receptor; IRAK1, interleukin 1 receptor associated kinase 1; JNK, c-Jun N-terminal kinase; KLF4, Kruppel like factor 4; LCN2, lipocalin 2; MAPkinase, mitogenactivated protein kinase; MCPIP1, monocyte chemoattractant protein-1 induced protein 1; MCP-1, monocyte chemoattractant protein1; MDSCs, myeloid-derived suppressive cells; miRISC, miRNAinduced silencing complex; MyD88, myeloid differentiation primary response gene 88; NEMO, NF-KB essential modulator; NF-kB, nuclear factor kappa B; NFKBIZ, NK-kappa-B inhibitor zeta; NSAIDs, non-steroidal anti-inflammatory drugs; PIN, PilT N-terminus; PPAR $\mathrm{Y}$, peroxisome proliferator activator receptor gamma; PPREs, peroxisome proliferator response elements; RNase, Ribonuclease; RORy, retinoid-related orphan receptor gamma; STAT, signal transducer and activator of transcription; TANK, TRAF family member associated NF-KB activator; TLR, Toll-like receptors; TNF, tumor necrosis factor; TRAF, TNF receptor associated factor; TRAIL, TNF-related apoptosis-inducing ligand; TTP, tristetraprolin; Ub, ubiquitin; USP, ubiquitin specific protease; USP10, ubiquitin specific peptidase 10; VEGF, vascular endothelial growth factor.

\section{ACKNOWLEDGEMENTS}

This work was supported by the Funds for the National Natural Science Foundation of China (Grant No. 81700201), Zhejiang Key Research and Development Project (2020C03014), National Major Scientific and Technological Special Project for "Significant New Drug Development" (2018ZX09733-003).

\section{COMPLIANCE WITH ETHICS GUIDELINES}

Ruyi Xu, Yi Li, Yang Liu, Jianwei Qu, Wen Cao, Enfan Zhang, Jingsong $\mathrm{He}$, and Zhen Cai declare that they have no conflict of interest. This article does not contain any studies with human or animal subjects performed by the any of the authors.

\section{OPEN ACCESS}

This article is licensed under a Creative Commons Attribution 4.0 International License, which permits use, sharing, adaptation, 
distribution and reproduction in any medium or format, as long as you give appropriate credit to the original author(s) and the source, provide a link to the Creative Commons licence, and indicate if changes were made. The images or other third party material in this article are included in the article's Creative Commons licence, unless indicated otherwise in a credit line to the material. If material is not included in the article's Creative Commons licence and your intended use is not permitted by statutory regulation or exceeds the permitted use, you will need to obtain permission directly from the copyright holder. To view a copy of this licence, visit http:// creativecommons.org/licenses/by/4.0/.

\section{REFERENCES}

Algra AM, Rothwell PM (2012) Effects of regular aspirin on long-term cancer incidence and metastasis: a systematic comparison of evidence from observational studies versus randomised trials. Lancet Oncol 13(5):518-527

Boratyn E, Nowak I, Horwacik I, Durbas M, Mistarz A, Kukla M, Kaczówka P, Łastowska M, Jura J, Rokita H (2016) Monocyte chemoattractant protein-induced protein 1 overexpression modulates transcriptome, including microRNA, in human neuroblastoma cells. J Cell Biochem 117(3):694-707

Brana I, Calles A, LoRusso PM, Yee LK, Puchalski TA, Seetharam S, Zhong B, de Boer CJ, Tabernero J, Calvo E (2015) Carlumab, an anti-CC chemokine ligand 2 monoclonal antibody, in combination with four chemotherapy regimens for the treatment of patients with solid tumors: an open-label, multicenter phase $1 \mathrm{~b}$ study. Target Oncol 10(1):111-123

Chitu V, Stanley ER (2006) Colony-stimulating factor-1 in immunity and inflammation. Curr Opin Immunol 18(1):39-48

Coffelt SB, De Visser KE (2014) Cancer: inflammation lights the way to metastasis. Nature 507(7490):48-49

Colotta F, Allavena P, Sica A, Garlanda C, Mantovani A (2009) Cancer-related inflammation, the seventh hallmark of cancer: links to genetic instability. Carcinogenesis 30(7):1073-1081

Costinean S, Sandhu SK, Pedersen IM, Tili E, Trotta R, Perrotti D, Ciarlariello D, Neviani P, Harb J, Kauffman LR et al (2009) Src homology 2 domain-containing inositol-5-phosphatase and CCAAT enhancer-binding protein $\beta$ are targeted by miR-155 in B cells of $E \mu$ MiR-155 transgenic mice. Blood J Am Soc Hematol 114(7):1374-1382

Coussens LM, Zitvogel L, Palucka AK (2013) Neutralizing tumorpromoting chronic inflammation: a magic bullet? Science 339 (6117):286-291

Deng L, Wang C, Spencer E, Yang L, Braun A, You J, Slaughter C, Pickart C, Chen ZJ (2000) Activation of the IKB kinase complex by TRAF6 requires a dimeric ubiquitin-conjugating enzyme complex and a unique polyubiquitin chain. Cell 103(2):351-361

Dhamija S, Winzen R, Doerrie A, Behrens G, Kuehne N, Schauerte C, Neumann E, Dittrich-Breiholz O, Kracht M, Holtmann H (2013) Interleukin-17 (IL-17) and IL-1 activate translation of overlapping sets of mRNAs, including that of the negative regulator of inflammation, MCPIP1[J]. J Biol Chem 288(26):19250-19259

Diakos Cl, Charles KA, McMillan DC, Clarke SJ (2014) Cancerrelated inflammation and treatment effectiveness. Lancet Oncol 15(11):e493-e503
Dobosz E, Wilamowski M, Lech M, Bugara B, Jura J, Potempa J, Koziel J (2016) MCPIP-1, alias regnase-1, controls epithelial inflammation by posttranscriptional regulation of IL-8 production [J]. J Innate Immun 8(6):564-578

Dysthe M, Parihar R (2020) Myeloid-derived suppressor cells in the tumor microenvironment. In: Tumor microenvironment 2020. Springer, Cham, pp 117-140

Elinav E, Nowarski R, Thaiss CA, Hu B, Jin C, Flavell RA (2013) Inflammation-induced cancer: crosstalk between tumours, immune cells and microorganisms. Nat Rev Cancer 13(11):759

Fiori ME, Di Franco S, Villanova L, Bianca P, Stassi G, De Maria R (2019) Cancer-associated fibroblasts as abettors of tumor progression at the crossroads of EMT and therapy resistance. Mol Cancer 18(1):70

Folkman J (2002) Role of angiogenesis in tumor growth and metastasis. In: Seminars in oncology. WB Saunders, vol 29(6), pp 15-18

Fu M, Blackshear PJ (2017) RNA-binding proteins in immune regulation: a focus on $\mathrm{CCCH}$ zinc finger proteins. Nat Rev Immunol 17(2):130

Galdiero MR, Marone G, Mantovani A (2018) Cancer inflammation and cytokines. Cold Spring Harb Perspect Biol 10(8):a028662

Garderet L, Kuhnowski F, Berge B, Roussel M, Escoffre-Barbe M, Lafon I, Facon T, Leleu X, Karlin L, Perrot A et al (2018) Pomalidomide, cyclophosphamide, and dexamethasone for relapsed multiple myeloma. Blood 132(24):2555-2563

Garg AV, Amatya N, Chen K, Cruz JA, Grover P, Whibley N, Conti HR, Mir GH, Sirakova T, Childs EC et al (2015) MCPIP1 endoribonuclease activity negatively regulates interleukin-17mediated signaling and inflammation. Immunity 43(3):475-487

Gierach GL, Lacey JV, Schatzkin A, Leitzmann MF, Richesson D, Hollenbeck AR, Brinton LA (2008) Nonsteroidal anti-inflammatory drugs and breast cancer risk in the National Institutes of HealthAARP Diet and Health Study. Breast Cancer Res 10(2):R38

Gordon S, Martinez FO (2010) Alternative activation of macrophages: mechanism and functions. Immunity 32(5):593-604

Houghton J, Stoicov C, Nomura S, Rogers AB, Carlson J, Li H, Cai X, Fox JG, Goldenring JR, Wang TC (2004) Gastric cancer originating from bone marrow-derived cells. Science 306 (5701):1568-1571

Huang S, Miao R, Zhou Z, Wang T, Liu J, Liu G, Chen YE, Xin HB, Zhang J, Fu M (2013) MCPIP1 negatively regulates toll-like receptor 4 signaling and protects mice from LPS-induced septic shock. Cell Signal 25(5):1228-1234

Huang S, Liu S, Fu JJ, Wang TT, Yao X, Kumar A, Liu G, Fu M (2015) Monocyte chemotactic protein-induced protein 1 and 4 form a complex but act independently in regulation of interleukin6 mRNA degradation. J Biol Chem 290(34):20782-20792

Iwasaki H, Takeuchi O, Teraguchi S, Matsushita K, Uehata T, Kuniyoshi K, Satoh T, Saitoh T, Matsushita M, Standley DM et al (2011) The IKB kinase complex regulates the stability of cytokineencoding mRNA induced by TLR-IL-1R by controlling degradation of regnase-1. Nat Immunol 12(12):1167

Jeltsch KM, Hu D, Brenner S, Zöller J, Heinz GA, Nagel D, Vogel KU, Rehage N, Warth SC, Edelmann SL et al (2014) Cleavage of roquin and regnase- 1 by the paracaspase MALT1 releases their 
cooperatively repressed targets to promote $\mathrm{T} \mathrm{H} 17$ differentiation. Nat Immunol 15(11):1079

Jiang H, Lv X, Lei X, Yang Y, Yang X, Jiao J (2016) Immune regulator MCPIP1 modulates TET expression during early neocortical development. Stem cell Rep 7(3):439-453

Kapoor N, Niu J, Saad Y, Kumar S, Sirakova T, Becerra E, Li X, Kolattukudy PE (2015) Transcription factors STAT6 and KLF4 implement macrophage polarization via the dual catalytic powers of MCPIP. J Immunol 194(12):6011-6023

Karin M, Greten FR (2005) NF-kB: linking inflammation and immunity to cancer development and progression. Nat Rev Immunol 5(10):749-759

Kasza A, Wyrzykowska P, Horwacik I, Tymoszuk P, Mizgalska D, Palmer K, Rokita H, Sharrocks AD, Jura J (2010) Transcription factors Elk-1 and SRF are engaged in IL1-dependent regulation of ZC3H12A expression. BMC Mol Biol 11(1):14

Leggas M, Kuo KL, Robert F, Cloud G, Deshazo M, Zhang R, Li M, Wang $H$, Davidson S, Rinehart J (2009) Intensive anti-inflammatory therapy with dexamethasone in patients with non-small cell lung cancer: effect on chemotherapy toxicity and efficacy. Cancer Chemother Pharmacol 63(4):731-743

Li M, Cao W, Liu H, Zhang W, Liu X, Cai Z, Guo J, Wang X, Hui Z, Zhang $\mathrm{H}$ et al (2012) MCPIP1 down-regulates IL-2 expression through an ARE-independent pathway[J]. PLoS One 7(11): e49841

Liang J, Wang J, Azfer A, Song W, Tromp G, Kolattukudy PE, Fu M (2008) A novel CCCH-zinc finger protein family regulates proinflammatory activation of macrophages. J Biol Chem 283 (10):6337-6346

Liang J, Saad Y, Lei T, Wang J, Qi D, Yang Q, Kolattukudy PE, Fu M (2010) MCP-induced protein 1 deubiquitinates TRAF proteins and negatively regulates JNK and NF-kB signaling. J Exp Med 207(13):2959-2973

Lu W, Ning H, Gu L, Peng H, Wang Q, Hou R, Fu M, Hoft DF, Liu J (2016) MCPIP1 selectively destabilizes transcripts associated with an antiapoptotic gene expression program in breast cancer cells that can elicit complete tumor regression. Cancer Res 76 (6):1429-1440

Maman S, Witz IP (2018) A history of exploring cancer in context. Nat Rev Drug Discov 17(3):13-30

Mantovani A, Allavena P, Sica A, Balkwill F (2008) Cancer-related inflammation. Nature 454(7203):436-444

Marcuzzi E, Angioni R, Molon B, Calì B (2019) Chemokines and chemokine receptors: orchestrating tumor metastasization. Int $\mathrm{J}$ Mol Sci 20(1):96

Marona P, Górka J, Mazurek Z, Wilk W, Rys J, Majka M, Jura J, Miekus K (2017) MCPIP1 downregulation in clear cell renal cell carcinoma promotes vascularization and metastatic progression. Cancer Res 77(18):4905-4920

Matsushita K, Takeuchi O, Standley DM, Kumagai Y, Kawagoe T, Miyake T, Satoh T, Kato H, Tsujimura T, Nakamura H et al (2009) Zc3h12a is an RNase essential for controlling immune responses by regulating mRNA decay. Nature 458(7242):1185-1190

Miao R, Huang S, Zhou Z, Quinn T, Van Treeck B, Nayyar T, Dim D, Jiang Z, Papasian CJ, Eugene Chen $Y$ et al (2013) Targeted disruption of MCPIP1/Zc3h12a results in fatal inflammatory disease. Immunol Cell Biol 91(5):368-376
Mino T, Murakawa Y, Fukao A, Vandenbon A, Wessels HH, Ori D, Uehata T, Tartey S, Akira S, Suzuki Y et al (2015) Regnase-1 and roquin regulate a common element in inflammatory mRNAs by spatiotemporally distinct mechanisms. Cell 161(5):1058-1073

Mizgalska D, Wegrzyn P, Murzyn K, Kasza A, Koj A, Jura J, Jarzab B, Jura J (2009) Interleukin-1-inducible MCPIP protein has structural and functional properties of RNase and participates in degradation of IL-1 $\beta$ mRNA. FEBS J 276(24):7386-7399

Monin L, Gudjonsson JE, Childs EE, Amatya N, Xing X, Verma AH, Coleman BM, Garg AV, Killeen M, Mathers A et al (2017) MCPIP1/regnase-1 restricts IL-17A-and IL-17C-dependent skin inflammation. J Immunol 198(2):767-775

Murray PJ (2017) Macrophage polarization. Annu Rev Physiol 10 (79):541-566

Murray PJ, Allen JE, Biswas SK, Fisher EA, Gilroy DW, Goerdt S, Gordon S, Hamilton JA, Ivashkiv LB, Lawrence T et al (2014) Macrophage activation and polarization: nomenclature and experimental guidelines. Immunity 41(1):14-20

Muzio M, Natoli G, Saccani S, Levrero M, Mantovani A (1998) The human Toll signaling pathway: divergence of nuclear factor $\mathrm{KB}$ and JNK/SAPK activation upstream of tumor necrosis factor receptor-associated factor 6 (TRAF6). J Exp Med 187(12):20972101

Niu J, Azfer A, Zhelyabovska O, Fatma S, Kolattukudy PE (2008) Monocyte chemotactic protein (MCP)-1 promotes angiogenesis via a novel transcription factor, MCP-1-induced protein (MCPIP). J Biol Chem 283(21):14542-14551

Niu J, Shi Y, Xue J, Miao R, Huang S, Wang T, Wu J, Fu M, Wu ZH (2013) USP10 inhibits genotoxic NF-kB activation by MCPIP1facilitated deubiquitination of NEMO. The EMBO journal. 32 (24):3206-3219

O'Boyle G, Brain JG, Kirby JA, Ali S (2007) Chemokine-mediated inflammation: identification of a possible regulatory role for CCR2. Mol Immunol 44(8):1944-1953

Oh YT, Qian G, Deng J, Sun SY (2018) Monocyte chemotactic protein-induced protein-1 enhances DR5 degradation and negatively regulates DR5 activation-induced apoptosis through its deubiquitinase function. Oncogene 37(25):3415-3425

Ono M (2008) Molecular links between tumor angiogenesis and inflammation: inflammatory stimuli of macrophages and cancer cells as targets for therapeutic strategy. Cancer Sci 99(8):15011506

Prach AT, MacDonald TA, Hopwood DA, Johnston DA (1997) Increasing incidence of Barrett's oesophagus: education, enthusiasm, or epidemiology? The Lancet 350(9082):933

Qi Y, Liang J, She ZG, Cai Y, Wang J, Lei T, Stallcup WB, Fu M (2010) MCP-induced protein 1 suppresses TNFa-induced VCAM1 expression in human endothelial cells[J]. FEBS Lett 584 (14):3065-3072

Rodriguez A, Vigorito E, Clare S, Warren MV, Couttet P, Soond DR, Van Dongen S, Grocock RJ, Das PP, Miska EA et al (2007) Requirement of bic/microRNA-155 for normal immune function. Science 316(5824):608-611

Rothwell PM, Wilson M, Price JF, Belch JF, Meade TW, Mehta Z (2012) Effect of daily aspirin on risk of cancer metastasis: a study of incident cancers during randomised controlled trials. The Lancet. 379(9826):1591-1601 
Roy A, Zhang M, Saad Y, Kolattukudy PE (2013) Antidicer RNAse activity of monocyte chemotactic protein-induced protein-1 is critical for inducing angiogenesis. Am J Physiol Cell Physiol 305 (10):C1021-C1032

Singhal S, Stadanlick J, Annunziata MJ, Rao AS, Bhojnagarwala PS, O'Brien S, Moon EK, Cantu E, Danet-Desnoyers G, Ra HJ et al (2019) Human tumor-associated monocytes/macrophages and their regulation of $\mathrm{T}$ cell responses in early-stage lung cancer. Sci Transl Med 11(479):eaat1500

Skalniak L, Mizgalska D, Zarebski A, Wyrzykowska P, Koj A, Jura J (2009) Regulatory feedback loop between NF-KB and MCP-1induced protein 1 RNase. FEBS J 276(20):5892-5905

Skalniak L, Koj A, Jura J (2013) Proteasome inhibitor MG-132 induces MCPIP 1 expression. FEBS J 280(11):2665-2674

Sønder SU, Saret S, Tang W, Sturdevant DE, Porcella SF, Siebenlist U (2011) IL-17-induced NF-KB activation via CIKS/Act1 physiologic significance and signaling mechanisms. J Biol Chem 286 (15):12881-12890

Stoeltzing O, Meric-Bernstam F, Ellis LM (2006) Intracellular signaling in tumor and endothelial cells: the expected and yet again, the unexpected. Cancer Cell 10(2):89-91

Suzuki $\mathrm{HI}$, Arase M, Matsuyama H, Choi YL, Ueno T, Mano H, Sugimoto K, Miyazono K (2011) MCPIP1 ribonuclease antagonizes dicer and terminates microRNA biogenesis through precursor microRNA degradation. Mol Cell 44(3):424-436

Takeuchi O (2018) Endonuclease regnase-1/monocyte chemotactic protein-1-induced protein-1 (MCPIP1) in controlling immune responses and beyond. Wiley Interdiscip Rev RNA 9(1):e1449

Uehata $T$, Iwasaki $H$, Vandenbon A, Matsushita K, HernandezCuellar E, Kuniyoshi K, Satoh T, Mino T, Suzuki Y, Standley DM et al (2013) Malt1-induced cleavage of regnase-1 in CD4 ${ }^{+}$helper T cells regulates immune activation. Cell 153(5):1036-1049
Voronov E, Shouval DS, Krelin Y, Cagnano E, Benharroch D, Iwakura Y, Dinarello CA, Apte RN (2003) IL-1 is required for tumor invasiveness and angiogenesis. Proc Natl Acad Sci 100 (5):2645-2650

Wynn TA, Chawla A, Pollard JW (2013) Macrophage biology in development, homeostasis and disease. Nature 496(7446):445455

Xiao C, Srinivasan L, Calado DP, Patterson HC, Zhang B, Wang J, Henderson JM, Kutok JL, Rajewsky K (2008) Lymphoproliferative disease and autoimmunity in mice with increased miR-17-92 expression in lymphocytes. Nat Immunol 9(4):405-414

Xu J, Peng W, Sun Y, Wang X, Xu Y, Li X, Gao G, Rao Z (2012a) Structural study of MCPIP1 N-terminal conserved domain reveals a PIN-like RNase. Nucleic Acids Res 40(14):6957-6965

Xu J, Fu S, Peng W, Rao Z (2012b) MCP-1-induced protein-1, an immune regulator. Protein Cell 3(12):903-910

Xu R, Li Y, Yan H, Zhang E, Huang X, Chen Q, Chen J, Qu J, Liu Y, $\mathrm{He} J$ et al (2019) CCL2 promotes macrophages-associated chemoresistance via MCPIP1 dual catalytic activities in multiple myeloma. Cell Death Dis 10(10):1-7

Yao H, Ma R, Yang L, Hu G, Chen X, Duan M, Kook Y, Niu F, Liao K, $\mathrm{Fu} \mathrm{M}$ et al (2014) MiR-9 promotes microglial activation by targeting MCPIP1. Nat Commun 5(1):1-2

Zheng Y, Yang J, Qian J, Qiu P, Hanabuchi S, Lu Y, Wang Z, Liu Z, Li $\mathrm{H}, \mathrm{He} \mathrm{J}$ et al (2013) PSGL-1/selectin and ICAM-1/CD18 interactions are involved in macrophage-induced drug resistance in myeloma. Leukemia 27(3):702-710

Zhou L, Azfer A, Niu J, Graham S, Choudhury M, Adamski FM, Younce C, Binkley PF, Kolattukudy PE (2006) Monocyte chemoattractant protein-1 induces a novel transcription factor that causes cardiac myocyte apoptosis and ventricular dysfunction. Circ Res 98(9):1177-1185 